\title{
STABLE-CARBON ISOTOPE TIME SERIES FROM TROPICAL TREE RINGS INDICATE A PRECIPITATION SIGNAL
}

\author{
ESTHER FICHTLER $^{1 *}$, GERHARD HELLE ${ }^{2}$, and MARTIN WORBES ${ }^{1}$ \\ ${ }^{1}$ Georg August Universität Göttingen, Department of Crop Sciences, Agronomy in the Tropics, Grisebachstrasse 6, 37077 \\ Göttingen, Germany \\ ${ }^{2}$ Institute of Chemistry and Dynamics of the Geosphere, Research Centre Jülich, ICG-5, 52425 Jülich, Germany
}

\begin{abstract}
Although studies on stable-carbon isotopes in trees from temperate zones provide abundant paleoclimatic data, tropical trees are still understudied in this context. Therefore this study examined the variability of intra- and inter-annual stable-carbon isotopic pattern in several tree species from various tropical climates. The $\delta^{13} \mathrm{C}$ values of samples of 12 broadleaved trees (seven species) from various paleotropical and neotropical sites along a climatic moisture gradient were investigated. The inter-annual variability between species and sites was studied. Further the relationship between $\delta^{13} \mathrm{C}$ and precipitation time series was analyzed. Results show that tropical tree species show a similar variability in carbon isotopic composition as temperate tree species. Significant correlations between annual precipitation and tree-ring $\delta^{13} \mathrm{C}$ time series were negative. Successful crossdating of a tree-ring $\delta^{13} \mathrm{C}$ time series highlights the potential of carbon isotope measurements for tropical tree-ring analytical studies. Tropical broadleaved trees are able to capture a carbon isotopic signal in their annual rings even under everwet conditions and show good potential for paleoclimatic research.
\end{abstract}

Keywords: $\delta^{13} \mathrm{C}$, stable carbon isotopes, dendrochronology, tree ring, tropics, tropical climate.

\section{INTRODUCTION}

The analysis of responses of trees to changing climate is a current challenge in global environmental research. A powerful and appropriate tool is the interpretation of tree-ring parameters, like ring width, wood density or stable isotopes. Because of annually recurring periods of slow growth or dormancy, wood anatomical differences appear as annual rings in cross-sections of tree stems. Tree-ring features and their variability store information on past growth conditions and can therefore contain paleoclimatic information. Many studies have proven the existence of annual rings in tree species in tropical regions from arid zones (Gourlay 1995; Stahle et al. 1999; Fichtler et al. 2004; Trouet et al. 2006) to humid zones (Fichtler et al. 2003), mangroves (Menezes et al. 2003; Verheyden et al. 2004a) and swamps (Callado et al. 2001). They all showed that rings in tropical trees appear with similar anatomical

\footnotetext{
*Corresponding author: enaumer@gwdg.de
}

structures, just as rings in temperate tree species, driven by periods of slow growth caused by the periodicity of rainfall events. Unlike in temperate zones, relatively few applications were developed for tropical regions (Worbes et al. 2003; Schöngart et al. 2004, 2006; Brienen and Zuidema 2005, 2006), despite numerous reports on the potential of tree-ring analysis in tropical trees (Worbes 2002 and citations therein). Inter alia, this is caused by limited technical facilities and financial resources in tropical countries themselves, but also difficultto-access stands and low sampling replication because of the enormous species diversity that comes along with low abundances of individuals of any particular species in most tropical forests. Furthermore, standard methods like coring are not suitable for most tropical trees, easily accessible forest stands are often protected, and exportation of wood discs is subject to strict regulations or even prohibited.

Studies on stable-carbon isotopes in the wood of temperate tree species have reported that the 
fractionation of ${ }^{13} \mathrm{C}$ in $\mathrm{C}_{3}$ plants varies with water stress (Ehleringer and Cooper 1988), solar radiation (Ehleringer et al. 1986), and plant nutrition (Livingston et al. 1999). These variations were studied on an inter-annual basis, using tree rings as records of the past, with special regards to their relation to climate (Leavitt and Long 1989, 1991; Danis et al. 2006; Gagen et al. 2006) and the possibility of using tree-ring stable-carbon time series as proxies for climate reconstruction. Dendroclimatology in the tropics is yet at an early stage, although paleoclimatic records from tropical regions are essential to our understanding of past changes in the Earth's climatic system, equator-to-pole linkages, and the prediction of sensitivity of tropical regions to future climate change (Robertson et al. 2006).

The content of ${ }^{13} \mathrm{C}$ in wood tissue of $\mathrm{C}_{3}$ plants is described as a function of (1) the fractionation caused by diffusion of $\mathrm{CO}_{2}$ through the stomata and by enzymatic $\mathrm{CO}_{2}$ fixation, (2) the ratio of the intercellular to atmospheric $\mathrm{CO}_{2}$ concentration, and (3) the source value given by the isotopic composition of atmospheric $\mathrm{CO}_{2}$ (Farquhar et al. 1989). Accordingly, leaves use internal $\mathrm{CO}_{2}$ for photosynthetic processes and, when stomatal closure takes place because of lack of moisture, the $\mathrm{CO}_{2}$ fixing enzyme discriminates less against ${ }^{13} \mathrm{C}$ in relation to the generally preferred ${ }^{12} \mathrm{C}$. This results in a higher (less negative) $\delta^{13} \mathrm{C}$ value of organic matter. As tropical trees undergo the same photosynthetic mechanisms, a carbon isotopic signal reflecting varying hydroclimatic conditions should be stored in their annual increments. Very few studies have been published on the stable-carbon isotope composition of tropical wood, usually with restricted geographical distribution (Tarhule and Leavitt 2004; Verheyden et al. 2004b; Hietz et al. 2005; Robertson et al. 2006; Gebrekirstos et al. 2009). In the present study we investigated stablecarbon isotope ratios in wood from Terminalia tree species and two other species growing under different precipitation regimes from 675 to $4,015 \mathrm{~mm}$ mean annual precipitation and annually recurring dry periods ranging from zero to seven months. The objectives of the study were a) to examine the intra- and inter-annual variability of carbon isotope ratios along a moisture gradient, and b) to test whether or not an annual precipitation signal is contained within the carbon isotope series.

\section{MATERIAL AND METHODS}

\section{Study Species and Sites}

A total of 12 discs, originating from the collection of tropical stem discs of the Department of Crop Sciences, Agronomy in the Tropics, University of Göttingen, Germany, were included in the study. For all discs, information on felling date and site conditions exist. To test the sensitivity of tree species to drought, trees within one taxon, the genus Terminalia LinN (family Combretaceae), were chosen from sites along a moisture gradient from very arid to perhumid (Table 1a). To test species specific adaptations, two different species (Cedrela odorata, Swietenia macrophylla) of the family Meliaceae were added to the sample set. To compare the overall mean values of $\delta^{13} \mathrm{C}$ of tree individuals with the general hydroclimatic conditions at the sites, $\delta^{13} \mathrm{C}$ coresults from earlier radiocarbon dating of nine tree individuals (Worbes 1999a; Fichtler et al. 2003) were added to the sample set ( $c f$. Table 1b).

Details on sites and species are listed in Table 1a. Katima Mulilo, Namibia, represents the driest site of the sample set with a mean annual precipitation of $675 \mathrm{~mm}$ and a dry period (monthly precipitation $<50 \mathrm{~mm}$ ) lasting up to seven months. The most humid site is La Selva, Costa Rica, with a mean annual precipitation of $4,015 \mathrm{~mm}$ and a dry period of one month or less. For all sampling sites, monthly precipitation data from nearby meteorological stations were available for periods covering (at least parts of) the tree's life span. Monthly data for Katima Mulilo, Namibia, were provided by S. Nicholson (Meteorology Department, Florida State University; personal communication). The data for DoradoTumeremo, Venezuela, were available from the CVG-EDELCA División de Cuencas e Hidrología. For Biakoa, Cameroon, a mean precipitation data set was built out of time series for Bafia and Yaounde for which data were derived from the 
Table 1. Information on sampling sites and species for stable carbon isotope analyses (a) and radiocarbon dating (b); OD = obligate deciduous, $\mathrm{EG}=$ evergreen .

a)

\begin{tabular}{|c|c|c|c|c|c|c|c|c|}
\hline Site & $\begin{array}{l}\text { Geographical } \\
\text { position }\end{array}$ & $\begin{array}{l}\text { Mean } \\
\text { annual } \\
\text { rainfall } \\
\text { in } \mathrm{mm}\end{array}$ & $\begin{array}{l}\text { Length } \\
\text { of dry } \\
\text { period } \\
\text { in } \\
\text { months }\end{array}$ & $\begin{array}{l}\text { species } \\
\text { sampled }\end{array}$ & $\begin{array}{l}\text { Phenology } \\
\text { of trees }\end{array}$ & Tree Code & $\begin{array}{l}\text { No. of } \\
\text { rings } \\
\text { sampled }\end{array}$ & $\begin{array}{c}\text { Years } \\
\text { climate } \\
\text { data } \\
\text { available }\end{array}$ \\
\hline $\begin{array}{c}\text { Katima } \\
\text { Mulilo }\end{array}$ & $17^{\circ} 30^{\prime} \mathrm{S}, 24^{\circ} 17^{\prime} \mathrm{E}$ & 675 & $6-7$ & T. sericea & OD & Terse 43 & 9 & 9 \\
\hline (Namibia) & & & & T. sericea & OD & Terse 34 & 11 & 11 \\
\hline $\begin{array}{c}\text { Dorado- } \\
\text { Tumeremo } \\
\text { (Venezuela) }\end{array}$ & $06^{\circ} 55^{\prime} \mathrm{N}, 61^{\circ} 24^{\prime} \mathrm{W}$ & 1560 & $2-3$ & T. amazonia & $E G$ & Teram 621 & 21 & 21 \\
\hline Biakoa & $04^{\circ} 40^{\prime} \mathrm{N}, 11^{\circ} 32^{\prime} \mathrm{E}$ & 1570 & $2-4$ & T. superba & OD & Tersu 753 & 10 & 6 \\
\hline (Cameroon) & & & & & OD & Tersu 584 & 87 & 31 \\
\hline \multirow{4}{*}{$\begin{array}{c}\text { Caparo } \\
\text { (Venezuela) }\end{array}$} & $07^{\circ} 26^{\prime} \mathrm{N}, 70^{\circ} 55^{\prime} \mathrm{W}$ & 1750 & $2-4$ & T. guyanensis & $E G$ & Tergu 455 & 13 & 13 \\
\hline & & & & T. guyanensis & $E G$ & Tergu 756 & 29 & 29 \\
\hline & & & & C. odorata & OD & Cedod 754 & 22 & 22 \\
\hline & & & & S. macrophylla & OD & Swima 230 & 10 & 10 \\
\hline $\begin{array}{c}\text { Km 98 } \\
\text { Sierra de } \\
\text { Lema } \\
\text { (Venezuela) }\end{array}$ & $06^{\circ} 06^{\prime} \mathrm{N}, 61^{\circ} 23^{\prime} \mathrm{W}$ & 2975 & $1-2$ & T. amazonia & $E G$ & Teram 628 & 24 & 19 \\
\hline $\begin{array}{c}\text { Uriman } \\
\text { (Venezuela) }\end{array}$ & $05^{\circ} 60^{\prime} \mathrm{N}, 62^{\circ} 65^{\prime} \mathrm{W}$ & 3890 & $1-2$ & T. quintalata & $E G$ & Terqu 453 & 27 & 23 \\
\hline $\begin{array}{c}\text { La Selva } \\
\text { (Costa Rica) }\end{array}$ & $10^{\circ} 26^{\prime} \mathrm{N}, 83^{\circ} 59^{\prime} \mathrm{W}$ & 4015 & $0-1$ & T. amazonia & $E G$ & Teram 445 & 14 & 14 \\
\hline
\end{tabular}

b)

\begin{tabular}{|c|c|c|c|c|}
\hline Site & $\begin{array}{l}\text { Geographical } \\
\text { position }\end{array}$ & $\begin{array}{l}\text { Mean } \\
\text { annual } \\
\text { rainfall } \\
\text { in } \mathrm{mm}\end{array}$ & $\begin{array}{l}\text { Length } \\
\text { of dry } \\
\text { period } \\
\text { in } \\
\text { months }\end{array}$ & species sampled \\
\hline $\begin{array}{c}\text { Gran Sabana } \\
\text { (Venezuela) }\end{array}$ & $05^{\circ} 06^{\prime} \mathrm{N}, 60^{\circ} \mathrm{W}$ & 1880 & $0-4$ & $\begin{array}{l}\text { Sapotaceae (Juss.) } \\
\text { Ficus sp. (L.) } \\
\text { Manilkara sp.( Adans.) }\end{array}$ \\
\hline $\begin{array}{c}\text { La Selva } \\
\text { (Costa Rica) }\end{array}$ & $10^{\circ} 26^{\prime} \mathrm{N}, 83^{\circ} 59^{\prime} \mathrm{W}$ & 4015 & $0-1$ & $\begin{array}{l}\text { Simarouba amara (Aubl.) } \\
\text { Balizia elegans ((Ducke) Barneby \& J.W. Grimes) } \\
\text { Dipteryx panamensis ((Pittier) Record \& Mell) } \\
\text { Hymenolobium mesoamericanum (H.C. Lima) } \\
\text { Minquartia guianesis (Aubl.) } \\
\text { Pentaclethra macroloba (Kuntze) }\end{array}$ \\
\hline
\end{tabular}


KNMI climate explorer (Oldenborgh and Burgers 2005). For km 98 Sierra de Lema, Venezuela, data were available from MARNR Dirección de Hidrología y Metereología, and the data for Caparo and Uriman, Venezuela, were adopted from earlier tree-ring studies on these sites (Ortiz et al. 2006; Worbes 1999b). Finally, monthly precipitation data for La Selva, Costa Rica, were provided by the Organization of Tropical Studies (OTS 2007).

Two individuals of Terminalia sericea BuRCH EX DC from Katima Mulilo, Namibia, one juvenile and one mature tree, were analyzed. $T$. sericea is drought-deciduous and forms welldefined annual rings, defined by a marginal parenchyma band and variations in vessel density and size (Figure 1a). Individual trees belonging to the species Terminalia amazonia Exell were analyzed from each of three sites, DoradoTumeremo, Venezuela, km 98 Sierra de Lema, Venezuela, and La Selva, Costa Rica, respectively. T. amazonia is evergreen and forms annual tree rings defined by either fiber cell density variations, variation of vessel density and size, marginal parenchyma bands or a combination of two or more of these characteristics (Figure 1b). Two individuals of Terminalia superba ENGL. \& Diels from Biakoa, Cameroon, were analyzed. T. superba is drought deciduous and the distinct rings are defined by a delimiting marginal parenchyma band (Figure 1c). From Caparo, Venezuela, one individual of Cedrela odorata LINN and Swietenia macrophylla KING, respectively, as well as two individuals of Terminalia guyanensis EICHLER were sampled. C. odorata and $S$. macrophylla are obligately deciduous, whereas T. guyanensis is evergreen. All four individuals show well-defined tree rings, defined by delimiting marginal parenchyma bands in $C$. odorata and S. macrophylla (Figures 1d, 1e) and alternating patterns of parenchyma and fiber bands in T. guyanensis (Figure 1f). One individual of Terminalia quintalata MAGUiRE was sampled at Uriman, Venezuela. T. quintalata forms annual rings characterized by fiber cell density variations and an ambiguous band of fiber cells with smaller, fewer or no vessels, rather than a sharp and distinct boundary (Figure 1g).
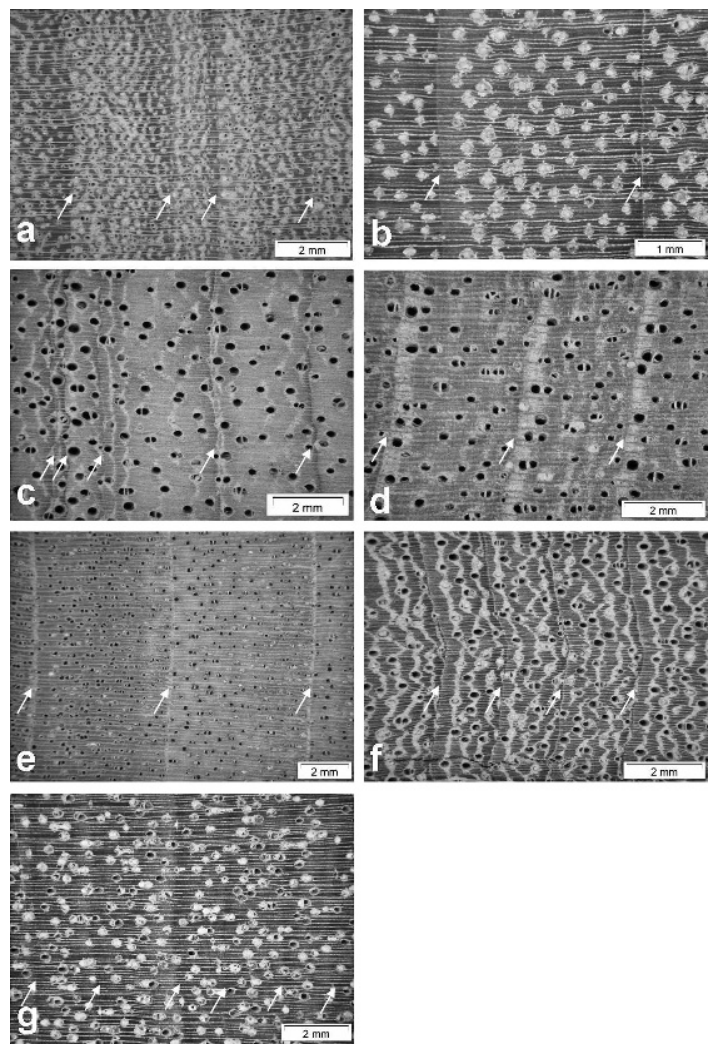

Figure 1. Sanded wood surfaces of sampled species: T. sericea (a), T. amazonia (b), T. superba (c), C. odorata (d), $S$. macrophylla (e), T. guyanensis (f) and $T$. quintalata (g). Images show tree rings (growing direction from left to right), white arrows indicate ring boundaries.

\section{Sample Preparation and Isotope Measurements}

The stem discs were polished with sandpaper up to 600 grit, and tree-ring boundaries were marked. Because felling dates were known, tree rings were dated by counting. For C. odorata 22 rings were analyzed at very fine resolution at the Institute of Chemistry and Dynamics of the Geosphere, Research Centre Jülich, Germany, following the sample preparation and measurements as described in Helle and Schleser (2004). For 11 discs, a section of one radius with clearly visible rings (with lengths between 9 and 87 years depending on the species) was defined for $\delta^{13} \mathrm{C}$ sampling. These radii were intra-annually subsampled with medium resolution, using a twist drill (Micromat 40E, Proxxon, Germany) with a 0.8 -mm-width bit that produced homogeneous 
wood powder. Samples were weighed and filled into tin capsules for stable isotope ratio mass spectrometry. Bulk wood samples were used, as recent studies on isotopic differences of bulk wood and wood components report only little or no differences in the variability of the carbon isotope signal (Borella et al. 1998; van de Water 2002; Loader et al. 2003). The stable-carbon isotope ratio was measured on-line using an NA 2500 elemental analyzer (CE Instruments, Italy) with an isotope ratio mass spectrometer MAT Delta ${ }^{\text {plus }}$ (Finnigan MAT, Germany) via a Con Flo III interface at the Centre for Stable Isotope Research and Analysis, Forest Ecosystem Research, University of Göttingen, Germany. All results are given in $\delta$-notation, i.e. the relative deviation from the PDB (Pee Dee Belemnite) standard:

$$
\delta^{13} \mathrm{C}=\left(R_{\text {sample }} / R_{\text {standard }}-1\right) \times 1000,
$$

where $R_{\text {sample }}$ and $R_{\text {standard }}$ are the ${ }^{13} \mathrm{C}^{12} \mathrm{C}$ ratios in a sample and standard, respectively.

\section{Statistical Analysis}

For each of the inter-annual analyses, the high- and medium-resolution measurements were averaged for the consecutive years as the tropical hardwood species used show only little or no density gradient within the rings. All annual series were detrended as the difference of the individual values from a linear regression of the entire series. For the detrended $\delta^{13} \mathrm{C}$ time series, correlation analyses were performed for either trees of the same species or individuals from the same sites. Further, the different $\delta^{13} \mathrm{C}$ time series were compared based on their Gleichläufigkeitskoeffizient (GLK), which is a measure of the year-toyear concurrence between the interval trends of two time series based upon the sign of concurrence (Kaennel and Schweingruber 1995). The GLKvalue gives the sum of equal slope intervals in $\%$.

Annual precipitation time series from nearby stations were built and detrended corresponding to the respective "growth year". For stations in the Northern Hemisphere, this is the sum of precipitation of all months from January to December, whereas for the site in the Southern Hemisphere it was the sum of all months from
August of the previous year to July of the current year (Walter and Lieth 1969). All correlation analyses of $\delta^{13} \mathrm{C}$ time series and climatic data sets were performed using Pearson's correlation with significance judged at $\mathrm{p}<0.05$. A minimum overlap period between $\delta^{13} \mathrm{C}$ time series and rainfall time series of 20 years was chosen.

The $\delta^{13} \mathrm{C}$ time series of a $T$. quintalata (Uriman, Venezuela) with unknown death year was tested for the suitability of these data for dating the tree. The disc of $T$. quintalata was taken in 1987 from a standing dead tree. Wood was sampled for $\delta^{13} \mathrm{C}$ measurements over a period of 27 years starting at the outermost intact ring towards the center. The time series of annual $\delta^{13} \mathrm{C}$ values were crossdated statistically and visually with annual rainfall time series by moving and matching the $\delta^{13} \mathrm{C}$ time series of the tree along the rainfall time series, starting with the sampling year going backwards in time.

The $\delta^{13} \mathrm{C}$ results from the radiocarbon measurements were derived from cellulose samples and had to be corrected with a factor of $-1.3 \%$ as Harlow et al. (2006) found this value as a mean difference between bulk wood and holocellulose component in a multi-species comparison of stable-carbon isotope values from wood samples with different chemical pretreatments. The mean, maximum and minimum $\delta^{13} \mathrm{C}$ values for the three individuals were correlated with annual mean rainfall conditions at the sampling sites.

\section{RESULTS}

The high-resolution $\delta^{13} \mathrm{C}$ profile with 8 to 186 measurements per ring of the $C$. odorata sample shows a definite annual pattern with lowest values at the ring boundaries (Figure 2). Increasing values at the beginning of the rings are followed by a $\delta^{13} \mathrm{C}$ decrease towards the end of the growth ring. The course and the amplitude of these annual curves vary from year to year. Within-ring variation was highest $(2.31 \%$ ) in the year 1968 and lowest $(0.80 \%$ ) in 1977 (Table 2). The overall level also differs among years between $-26.83 \%$ in 1975 and $-28.77 \%$ in 1979 (Table 2).

The medium-resolution $\delta^{13} \mathrm{C}$ profile of the Terminalia species with 1 to 16 measurements per 


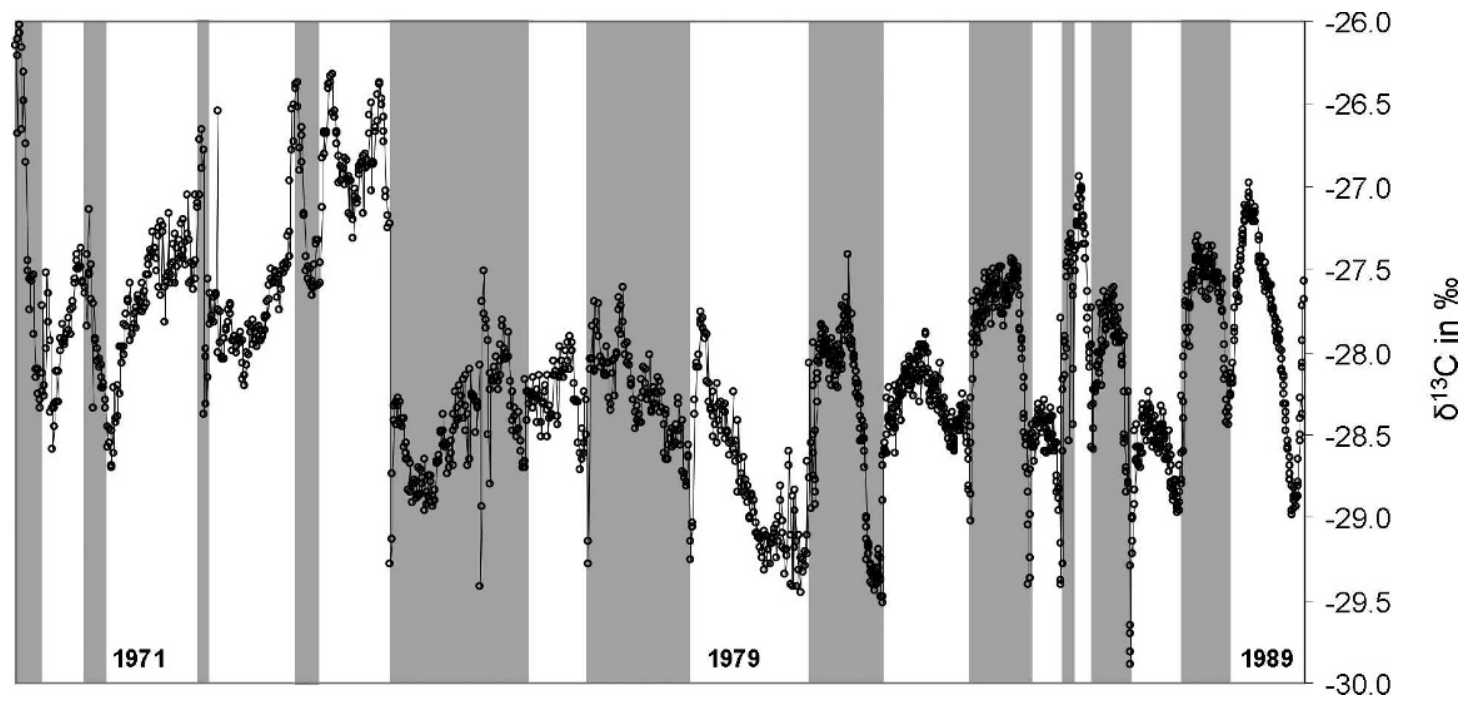

Figure 2. High-resolution $\delta^{13} \mathrm{C}$ profile of C. odorata from Caparo, Venezuela, for the years 1968-1989; white and gray areas indicate different years.

year also showed the distinctive pattern observed in the high-resolution profile for rings that were wide enough to make at least four to six measurements per ring (Figure 3a). In small rings allowing fewer than four measurements per ring, minimum values at the ring boundaries are no longer visible in any ring (Figure $3 b$ ). The course and the amplitude of the intra-annual $\delta^{13} \mathrm{C}$ values are variable in these profiles. The highest intraannual variation ( $c f$. Table 2) was found in $T$. sericea with $2.78 \%$ (1993) and the lowest variation was found in a ring of $T$. superba with $0.005 \%$ (1974). The radial pattern of mean annual carbon isotopes varied considerably between species and within trees. The minimum variation among different years within individual samples was very low in all individuals, the maximum inter-annual variation spanned between $0.43 \%$ for $T$. superba from Biakoa, Cameroon, and $4.98 \%$ for $T$. guyanensis from Caparo, Venezuela (Table 2). Annual mean values of all measured samples per tree species fall within the range of $-27.99 \%$ to $-23.43 \%$ o (Table 2).

The $\delta^{13} \mathrm{C}$ time series of two individual $T$. sericea trees from the arid site Katima Mulilo, Namibia, show an identical inter-annual $\delta^{13} \mathrm{C}$ pattern (Figure 4a). The individual series are significantly correlated $(r=0.89, p=0.001)$, the GLK of $100 \%$ is significant (Table 3). The overall mean $\delta^{13} \mathrm{C}$ is higher in the juvenile tree $(-24.70 \%)$ than in the mature tree $(-25.90 \%)$. The two $T$. superba samples from Biakoa, Cameroon, also show a similar inter-annual $\delta^{13} \mathrm{C}$ pattern and are significantly correlated at $\mathrm{r}=0.68(\mathrm{p}=0.030)$, and the GLK of $75 \%$ is high (Table 3, Figure $4 b$ ).

Three individual samples of $T$. amazonia from two sites in Venezuela and one site in Costa Rica covered an overlapping period of 21 years and 14 years, respectively. The individuals from Dorado-Tumeremo and km 98 Sierra de Lema, Venezuela, show similar year-to-year variability patterns expressed by a significant GLK value of $76 \%$ (Table 3). None are correlated with the time series of the Costa Rican sample from the same species. The overall mean values of the trees from Venezuela show the same range, but were considerably lower (more negative) in the sample from La Selva, Costa Rica (Figure 4c).

Within the four tree individuals from Caparo, Venezuela, only the two T. guyanensis individuals show a significant correlation and GLK $(\mathrm{r}=0.75$, $p=0.008$; GLK $=75 \%$; Figure $4 d)$. The overall mean $\delta^{13} \mathrm{C}$ levels of the $T$. guyanensis samples are in the same range, whereas $C$. odorata and $S$. macrophylla show lower mean values (Table 2).

Four series from living trees met the criterion of minimum 20-year overlap between the carbon and precipitation series namely $C$. odorata and $T$. 
Table 2. Descriptive statistics for the $\delta^{13} \mathrm{C}$ measurements of the 12 sampled trees (all values in \%o).

\begin{tabular}{|c|c|c|c|c|c|c|c|c|c|c|}
\hline & & \multirow[b]{2}{*}{ MEAN } & \multirow[b]{2}{*}{ MIN } & \multirow[b]{2}{*}{ MAX } & \multirow[b]{2}{*}{ Variance } & \multirow[b]{2}{*}{ Std Dev } & \multicolumn{2}{|c|}{$\begin{array}{c}\text { intra-annual } \\
\text { variation }\end{array}$} & \multicolumn{2}{|c|}{$\begin{array}{c}\text { inter-annual } \\
\text { variation }\end{array}$} \\
\hline & ree & & & & & & $\min$ & $\max$ & $\min$ & $\max$ \\
\hline Terse 43 & $\begin{array}{l}\text { (Katima } \\
\text { Mulilo, } \\
\text { Namibia) }\end{array}$ & -24.70 & -25.21 & -23.88 & 0.182 & 0.426 & 0.659 & 2.229 & 0.044 & 1.329 \\
\hline Terse 34 & $\begin{array}{l}\text { (Katima } \\
\text { Mulilo, } \\
\text { Namibia) }\end{array}$ & -25.90 & -26.59 & -24.57 & 0.287 & 0.536 & 0.221 & 2.781 & 0.015 & 2.022 \\
\hline Teram 621 & $\begin{array}{l}\text { (Dorado- } \\
\text { Tumeremo, } \\
\text { Venezuela) }\end{array}$ & -26.33 & -27.41 & -25.46 & 0.217 & 0.466 & 0.071 & 1.025 & 0.006 & 1.954 \\
\hline Tersu 753 & $\begin{array}{l}\text { (Biakoa, } \\
\text { Cameroon) }\end{array}$ & -23.43 & -23.62 & -23.19 & 0.016 & 0.127 & 0.272 & 0.947 & 0.009 & 0.434 \\
\hline Tersu 584 & $\begin{array}{l}\text { (Biakoa, } \\
\text { Cameroon) }\end{array}$ & -24.08 & -25.42 & -23.07 & 0.261 & 0.511 & 0.005 & 1.434 & 0.002 & 2.340 \\
\hline Tergu 455 & $\begin{array}{l}\text { (Caparo, } \\
\text { Venezuela) }\end{array}$ & -26.55 & -26.99 & -26.12 & 0.070 & 0.265 & 0.399 & 1.810 & 0.001 & 0.872 \\
\hline Tergu 756 & $\begin{array}{l}\text { (Caparo, } \\
\text { Venezuela) }\end{array}$ & -26.96 & -30.30 & -25.32 & 1.392 & 1.180 & 0.077 & 2.013 & 0.003 & 4.984 \\
\hline Cedod 754 & $\begin{array}{l}\text { (Caparo, } \\
\text { Venezuela) }\end{array}$ & -27.92 & -28.77 & -26.83 & 0.260 & 0.510 & 0.801 & 2.308 & 0.001 & 1.941 \\
\hline Swima 230 & $\begin{array}{l}\text { (Caparo, } \\
\text { Venezuela) }\end{array}$ & -27.80 & -28.60 & -27.40 & 0.159 & 0.399 & 0.668 & 2.504 & 0.005 & 1.207 \\
\hline Teram 628 & $\begin{array}{l}\text { (Km } 98 \text { Sierra } \\
\text { de Lema, } \\
\text { Venezuela) }\end{array}$ & -26.41 & -27.59 & -25.16 & 0.435 & 0.660 & 0.188 & 1.335 & 0.000 & 2.429 \\
\hline Terqu 453 & $\begin{array}{l}\text { (Uriman, } \\
\text { Venezuela) }\end{array}$ & -24.78 & -25.32 & -24.18 & 0.083 & 0.288 & 0.014 & 0.602 & 0.001 & 1.138 \\
\hline Teram 445 & $\begin{array}{l}\text { (La Selva, } \\
\text { Costa Rica) }\end{array}$ & -27.99 & -29.00 & -27.59 & 0.132 & 0.360 & 0.131 & 0.743 & 0.001 & 1.404 \\
\hline
\end{tabular}

guyanensis from Caparo,Venezuela, T. amazonia from Dorado-Tumeremo, Venezuela, as well as $T$. superba from Biakoa, Cameroon ( $c f$. Table 1). Three out of four show a significant correlation of annual $\delta^{13} \mathrm{C}$ values with annual rainfall series (Table 4). C. odorata is negatively correlated $(\mathrm{r}=$ $-0.59, \mathrm{p}=0.004$ ) with annual rainfall (Figure 5a), T. amazonia is negatively correlated $(\mathrm{r}=-0.55, \mathrm{p}$ $=0.009$ ) with annual rainfall (Figure 5b), and $T$. superba is negatively correlated $(\mathrm{r}=-0.44, \mathrm{p}=$ 0.013 ) with annual rainfall (Figure 5c).

To date the dead sampled T. quintalata tree by means of $\delta^{13} \mathrm{C}$, the time series of the tree was moved statistically along the mean annual precipitation time series and showed only one matching position in time. Dating the first analyzed ring to 1980 resulted in a significant and strongly negative correlation with annual precipitation $(r=-0.63$, $\mathrm{p}=0.001$; Figure $5 \mathrm{~d}$; Table 4). This suggests that the tree died after 1980 and remained standing dead until the sampling in 1987.

Significant negative correlations between mean, minimum and maximum measured $\delta^{13} \mathrm{C}$ for the 21 tree individuals and the mean annual rainfall of the study sites were found. The least negative measured values (MAX) showed the strongest correlation with mean annual rainfall at the site with $\mathrm{r}=-0.51, \mathrm{p}=0.018$ (Fig. 6; MEAN: $\mathrm{r}=-0.48, \mathrm{p}=0.029$; MIN: $\mathrm{r}=-0.45$, $\mathrm{p}$ $=0.042$ ). Excluding the dead sampled T. quintalata improves the correlations of all values (MAX: $\mathrm{r}=-0.56, \mathrm{p}=0.011 ;$ MEAN: $\mathrm{r}=-0.59, \mathrm{p}=$ 0.006; MIN: $r=-0.62, p=0.003)$.

\section{DISCUSSION}

The analysis of growth responses of trees to climatic changes and variation is a challenge to environmental research in the realm of global change. Many attempts have been undertaken to investigate adaptations of trees to drought stress, e.g. with photosynthesis and transpiration measurements (Borchert 1994; Cunningham 2005). Another promising tool is the interpretation of tree-ring time series. Substantial progress in understanding tree growth based on tree rings has been made in recent decades (Schweingruber 1996). A major focus of those investigations was 

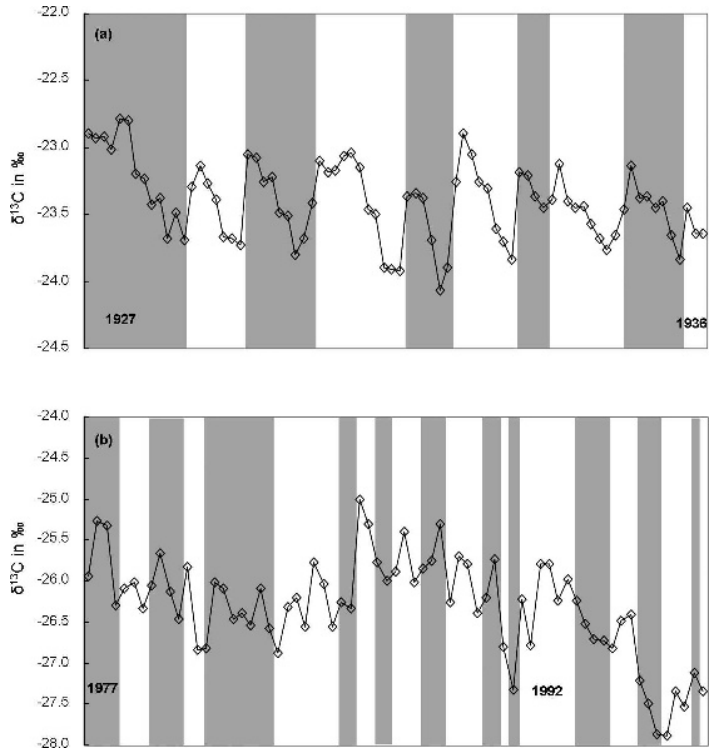

Figure 3. (a) Medium resolution $\delta^{13} \mathrm{C}$ profile of $T$. superba from Biakoa, Cameroon, for the years 1927-1936, (b) medium resolution $\delta{ }^{13} \mathrm{C}$ profile of $T$. amazonia from $\mathrm{km} 98$ Sierra de Lema, Venezuela, for the years 1977-1998; white and gray areas indicate different years.

tree-ring width measurements, which show strong climatic responses and allow the development of paleoclimatic reconstructions (e.g. Esper et al. 2002). The analysis of stable carbon isotope ratios in tree rings is a more recent approach that has primarily been applied on trees from temperate zones (Danis et al. 2006; Gagen et al. 2006). In our study we compared trees from different hydrological sites to define how rainfall variations are influencing ${ }^{13} \mathrm{C}$ fractionation in tropical trees to enable a better interpretation of stable isotope patterns in the wood. At high resolution we found a similar intra-annual pattern that is described for trees from temperate zones (Helle and Schleser 2004) as well as for mangrove trees from Kenya (Verheyden et al. 2004b). In all cases, lowest (most negative) $\delta^{13} \mathrm{C}$ values were found at the ring boundaries. During the vegetation period, values increase following varying trends from one year to the next, but all decrease towards the end with the exception of the very last ring (1989, cf. Figure 2) where there is an increase at the very end. Because this intra-annual behavior is observed under contrasting environmental site conditions it must be traced back to internal physiological processes.
Towards the end of a vegetation period, starch is stored in wood tissue as Dünisch and Puls (2003) showed for Amazonian Cedrela odorata trees. Starch, which is enriched in ${ }^{13} \mathrm{C}$, is remobilized at the beginning of the growing period for the formation of new wood tissue. This leads to an increase of ${ }^{13} \mathrm{C}$ in the wood during this time, while later in the growing period enriched leaf carbon is used for wood formation (Helle and Schleser, 2004). Towards the end of the vegetation period, an isotope partitioning between enriched starch and depleted cell-wall tissue leads to the observed decrease of ${ }^{13} \mathrm{C}$ in our high-resolution pattern at the ring boundaries (Heller and Schleser 2004). The observed increase in the youngest ring near the bark may be traced back to the fact that starch is mainly stored in this part of the ring. For our medium-scale analyses, the part of the growth zone very close to the boundaries could not be separated for sampling because the core hole with $0.8 \mathrm{~mm}$ diameter produces a composite sample that cannot distinguish the wood immediately adjacent to the ring boundary. Thus, future intraannual analysis may need to take this into consideration depending on the resolution of sub-sampling.

As mentioned above, the $\delta^{13} \mathrm{C}$ in the central parts of the tree rings show varying levels from year to year leading to the conclusion that these follow external growth-influencing factors. As an example, the years 1983 and 1987 were comparably wet in the Western-Llanos in Venezuela and the discrimination against ${ }^{13} \mathrm{C}$ in the wood of Cedrela odorata (Figure 2) was much higher than in the dry years 1984 and 1985. This supports the dominant influence of precipitation and water availability on $\delta^{13} \mathrm{C}$ over much of the period of ring formation.

We found some clear hints that $\delta^{13} \mathrm{C}$ varies considerably with the development of a tree, as many rain forest trees showed a significantly lower $\delta^{13} \mathrm{C}$ value in the earliest ring of the stem than in all outermost samples. This is caused by so-called isotope "juvenile effect". It reflects the potentially more ${ }^{13} \mathrm{C}$-depleted, respired soil $\mathrm{CO}_{2}$ that is a photosynthetic source for individuals growing close to the forest floor (Schleser and Jayasekera 1985). In addition, photosynthesis rates decrease 

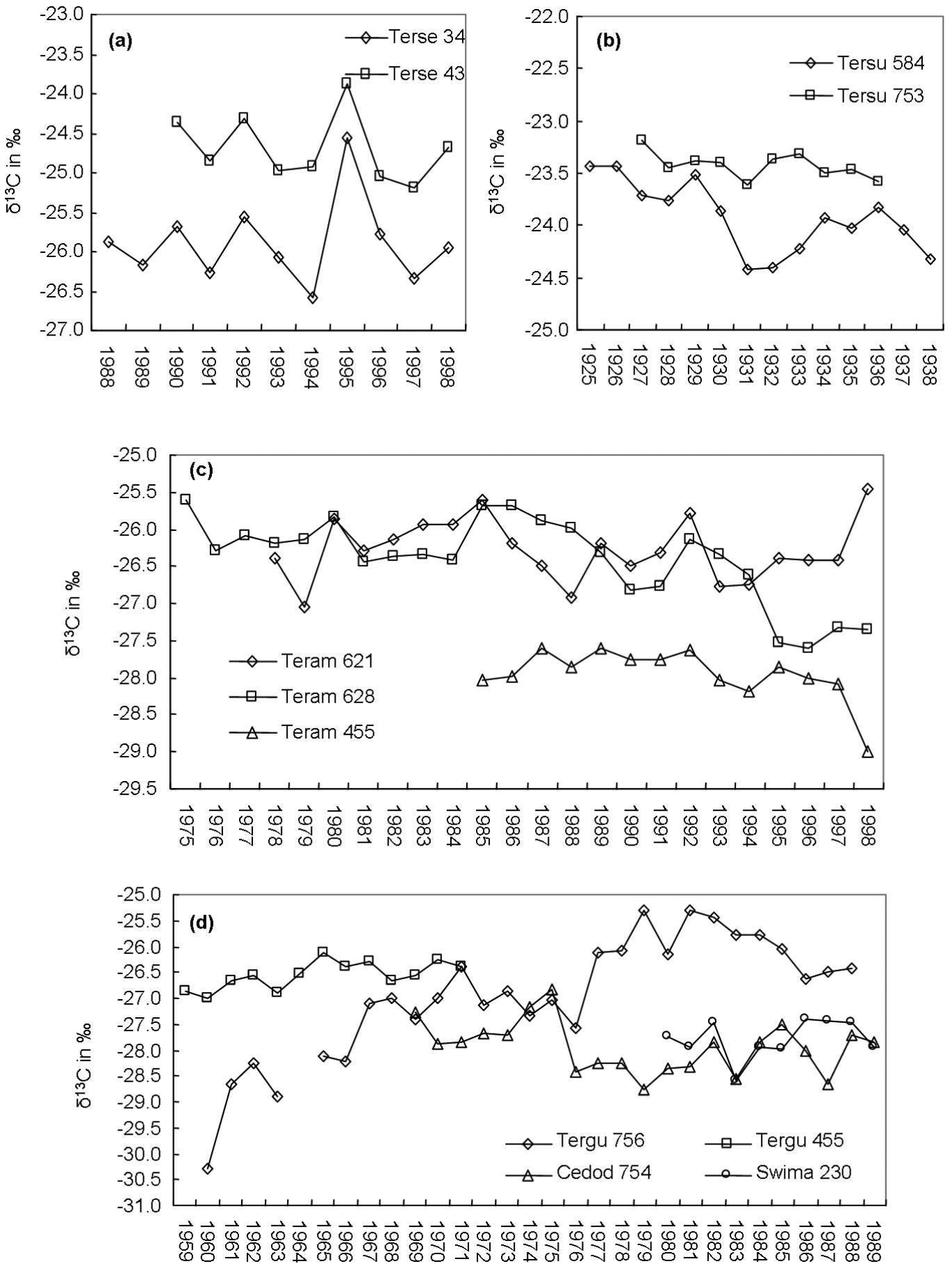

Figure 4. Inter-annual $\delta^{13} \mathrm{C}$ profile of (a) T. sericea (Terse 34 and Terse 43) from Katima Mulilo, Namibia, (b) T. superba (Tersu 584 and Tersu 753) from Biakoa, Cameroon, (c) T. amazonia from Dorado-Tumeremo (Teram 621) and Km98 Sierra de Lema (Teram 628), Venezuela and La Selva (Teram 445), Costa Rica, and (d) C. odorata (Cedod 754), T. guyanensis (Tergu 455 and Tergu 756$)$ and S. macrophylla (Swima 230) from Caparo, Venezuela. 
Table 3. Correlation results for $\delta^{13} \mathrm{C}$ time series of trees of the same species and/or from same site.

\begin{tabular}{|c|c|c|c|}
\hline Tree pairs & & $\mathbf{r}$ & GLK \\
\hline Terse 34 vs Terse 43 & (Katima Mulilo, Namibia) & $0.89 * *$ & $100^{* *}$ \\
\hline Tersu 584 vs Tersu 584 & (Biakoa, Cameroon) & $0.68^{*}$ & 75 \\
\hline Cedod 754 vs Swima 230 & (Caparo, Venezuela) & 0.2 & 63 \\
\hline Cedod 754 vs Tergu 455 & (Caparo, Venezuela) & $a$ & a \\
\hline Cedod 754 vs Tergu 756 & (Caparo, Venezuela) & $-0.49^{*}$ & 63 \\
\hline Swima 230 vs Tergu 455 & (Caparo, Venezuela) & a & a \\
\hline Swima 230 vs Tergu 756 & (Caparo, Venezuela) & -0.45 & 43 \\
\hline Tergu 455 vs Tergu 756 & (Caparo, Venezuela) & $0.75^{* *}$ & $75^{*}$ \\
\hline Teram 621 vs Teram 628 & $\begin{array}{l}\text { (Durado-Tumeremo vs Km } 98 \text { Sierra } \\
\text { de Lema, Venezuela) }\end{array}$ & 0.37 & $76^{\star \star}$ \\
\hline Teram 621 vs Teram 445 & $\begin{array}{l}\text { (Durado-Tumeremo, Venezuela vs La } \\
\text { Selva, Costa Rica) }\end{array}$ & 0.47 & 58 \\
\hline Teram 628 vs Teram 445 & $\begin{array}{l}\text { (Km } 98 \text { Sierra de Lema, Venezuela vs } \\
\text { La Selva, Costa Rica) }\end{array}$ & -0.06 & 63 \\
\hline
\end{tabular}

$a=$ no overlap; ${ }^{*} p<0.05 ;{ }^{* *} p<0.01$

because of the limited light conditions within closed forest stands and result in lower (more negative) $\delta^{13} \mathrm{C}$ values. This seems to be true for the tree individuals growing in the understorey of closed forests during their juvenile stage. In contrast, the high-resolution profile of $C$. odorata showed less negative $\delta^{13} \mathrm{C}$ values towards a young cambial age (youth) of the tree. Similarly the younger sample (Terse43) from $T$. sericea from Katima Mulilo, Namibia, showed higher values than the older individual (Terse 34). An explanation could be extreme drought stress during their juvenile phase as these two individuals grew in open stands or in a plantation and had to face full radiation when they had only a shallow rooting system.

In the present study, all $\delta^{13} \mathrm{C}$ time series of tree individuals of the same species from the same sites show significant correlations, indicating a common external factor that triggers stablecarbon isotope discrimination. Comparing different species from the same site or the same species from different sites, no consistent results were found. The variability in different species may depend to a large extent on species-specific properties, e.g. varying rooting depth or leaf anatomy, resulting in distinction of the species' sensitivity to climatic conditions at the same site.
S. macrophylla, which did not show a distinct climate signal, is reported to have a minimum rooting depth of $150 \mathrm{~cm}$. In contrast $C$. odorata with rooting depth of $50 \mathrm{~cm}$ (USDA, NRCS 2007) showed a higher sensitivity to rainfall, because the upper soil layers are more directly affected by rainfall variations. Borchert et al. (2002) report deep-rooting trees in tropical forests in Costa Rica to be less affected or unaffected by seasonal drought events.

To some extent a common signal is visible in the three $T$. amazonia trees from different sites. The annual precipitation time series of these three sites are significantly correlated and show high GLK values (La Selva, Costa Rica vs. DoradoTumeremo, Venezuela: $\mathrm{r}=0.422 *$, GLK $83 \% * *$; La Selva, Costa Rica vs. km98 Sierra de Lema, Venezuela: $\mathrm{r}=0.465^{*}$, GLK $76 \% * *$; DoradoTumeremo, Venezuela vs. km98 Sierra de Lema, Venezuela: $r=0.786^{* *}$, GLK $84 \% \%^{* *}$ ), indicating that these regions, although climatically different in the mean amount of rainfall, are subject to similar inter-annual variations in the periodicity and the absolute annual precipitation. Considering the similarities in $T$. amazonia samples that were collected at great distances from one another but which are influenced by analogous climatic 
Table 4. Correlation results for stable carbon isotope time series of trees and annual rainfall time series. T. quintalata was a dead tree, all others were living trees.

\begin{tabular}{ccc}
$\boldsymbol{\delta}^{13} \mathbf{C}$ index & Rainfall Index & $\mathbf{r}$ \\
\hline C. odorata & Caparo, Venezuela & $-\mathbf{0 . 5 9 ^ { \star * }}$ \\
\hline T. guyanensis & Caparo, Venezuela & -0.08 \\
$T$. amazonia & Dorado-Tumeremo, Venezuela & $-\mathbf{0 . 5 5 ^ { \star * }}$ \\
\hline T. superba & Biakoa, Cameroon & $-\mathbf{0 . 4 4 ^ { * }}$ \\
$T$. quintalata & Uriman, Venezuela & $-\mathbf{0 . 6 3 ^ { \star * }}$ \\
\hline${ }^{*} \mathrm{p}<0.05 ;{ }^{\star *} \mathrm{p}<0.01$ & &
\end{tabular}

variations, there is potential to study large-scale precipitation variations by analyzing tree rings of widely distributed individuals of the same species in areas where climatic parameters are strongly affected by hemispheric-scale circulation patterns (e.g. El Niño-Southern Oscillation).

The correlation between precipitation time series and tree-ring isotopic data was significantly negative. The significant correlations found were evenly strong and independent of the humidity differences of the sites or the phenology of the trees. Growth-limiting factors are typically reported as being responsible for the isotopic fractionation in plants (Robertson et al. 2006). The relationship between precipitation and stablecarbon isotope time series can be interpreted in this context. Where moisture availability is limiting, stomatal conductance dominates the carbon fractionation. McCarroll and Loader (2004) therefore concluded that the dominant control in trees that are rarely subject to drought stress, may be photosynthetic rate, which is primarily controlled by irradiance and temperature. Intra-annual temperature variations are small in the inner tropics and only changes in irradiance related to varying cloudiness could have a strong influence on photosynthetic rates. The significant correlation of $\delta^{13} \mathrm{C}$ in T. quintalata with precipitation from the perhumid site Uriman, Venezuela (Figure 5d), however, shows that moisture availability can be a limiting factor for tree growth, even under prevailing moist conditions. Trees at perhumid sites appear to be sensitive even to slight variations in precipitation. Studies at La Selva, Costa Rica, have shown that short rainless periods (10 to
21 days) during the drier months (Jan-Apr) every year lead to a brief but marked drop in soil moisture content (Schwendenmann et al. 2003) causing a strong periodicity of tree phenology (Frankie et al. 1974) and tree growth (Fichtler et al. 2003). In addition, Cunningham (2004) reported a higher stomatal sensitivity to vapor pressure deficit in tropical rainforest species than in temperate rainforest species. The generally negative correlation between $\delta^{13} \mathrm{C}$ in the wood tissue and rainfall is moreover affirmed by the negative correlation between $\delta^{13} \mathrm{C}$ values for tree individuals and the general hydrological condition at the growing site found in this study.

The successful crossdating of the T. quintalata $\delta^{13} \mathrm{C}$ time series highlights the potential of carbon isotope measurements for tropical treering analytical studies. As in many other tropical species, conventional tree-ring analysis methods may fail in this particular species because of the ambiguous tree-ring boundaries (Figure 1g).

The results of this study show that tropical trees, like temperate trees, are recording carbon isotopic signals in the wood, which can be linked to common external factors. The analyses of treering isotopic data in tropical trees with an annual resolution must be expanded in sample size and length to gain more insights into the particular factors influencing carbon isotope fractionation processes in tropical trees. A combination of several factors controls $\delta^{13} \mathrm{C}$ variability under most conditions (Leavitt 2002), thereby requiring further investigation to identify the relative influence of various factors on growth conditions and carbon isotope fractionation in tropical trees. 


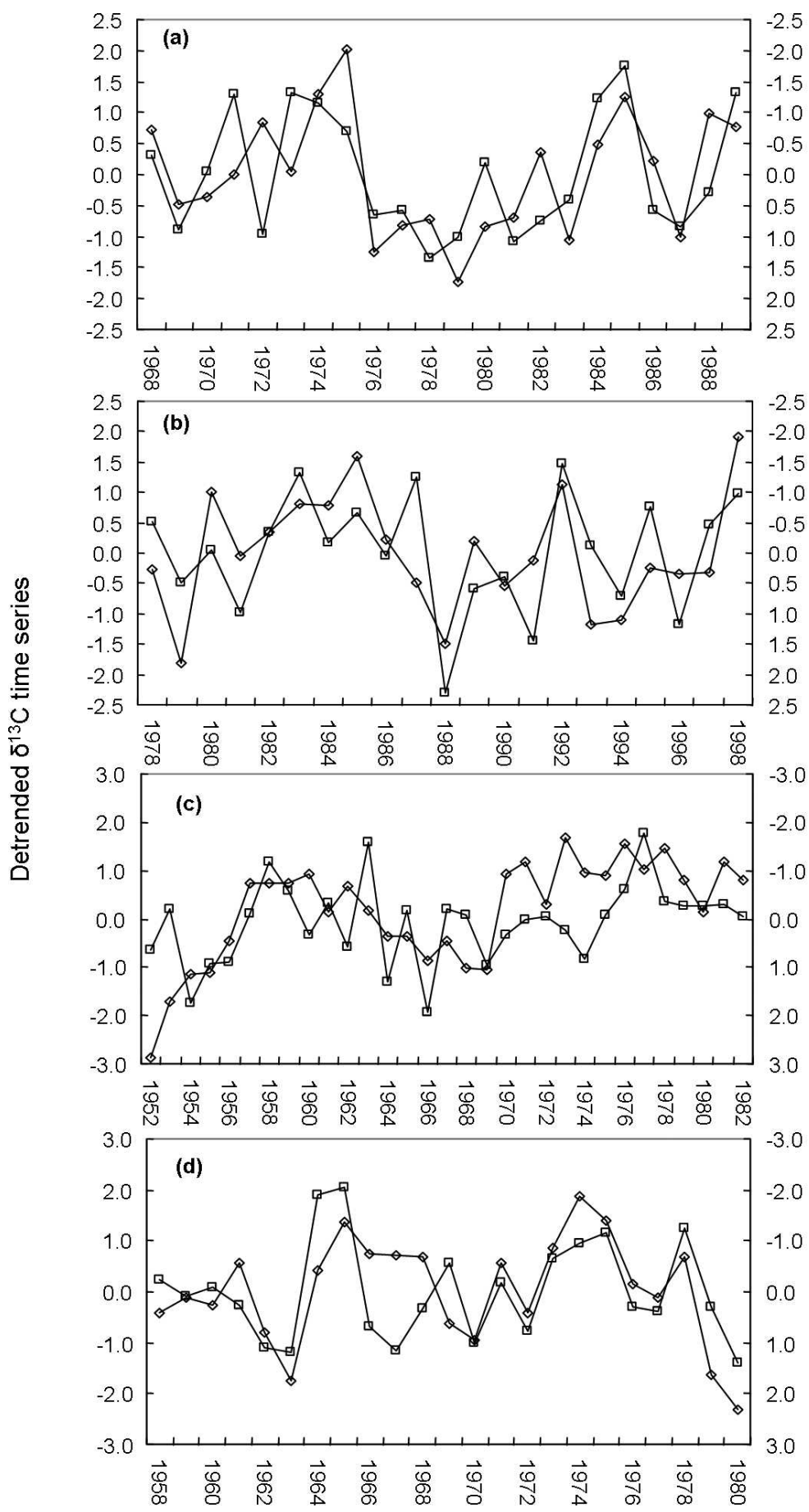

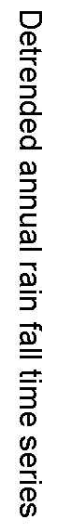

Figure 5. Detrended inter-annual $\delta^{13} \mathrm{C}$ profiles (diamonds) and detrended annual rainfall time series (squares) of (a) C. odorata from Caparo, Venezuela, (b) T. amazonia from Dorado-Tumeremo, Venezuela, (c) T. superba from Biakoa, Cameroon, and (d), T. quintalata from Uriman, Venezuela. Note the inverse axis for detrended rainfall series. 


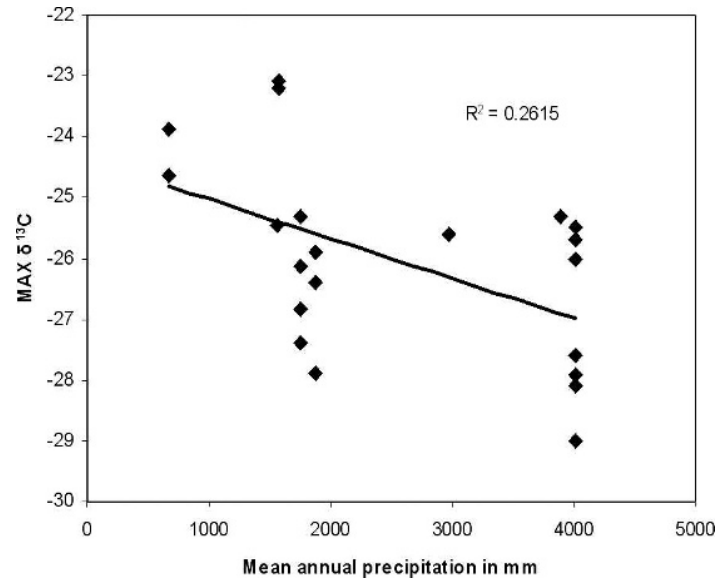

Figure 6. Trend of maximum annual $\delta^{13} \mathrm{C}$ in relation to mean annual rainfall in $\mathrm{mm}$ of the sites. Plotted data include corrected $\delta^{13} \mathrm{C}$ values from radiocarbon studies listed in Table $1 \mathrm{~b}$.

Factors such as stand position and competition pressure, associated with diversity in light and water availability, should be considered when selecting trees, to achieve a more homogeneous sample set. Future isotopic investigations on tropical tree rings could provide valuable tools for paleoclimatic studies in tropical regions.

\section{ACKNOWLEDGMENTS}

E. Fichtler was financed by the Scholarship Programme of the Deutsche Bundesstiftung Umwelt. We are grateful for the precipitation data provided by Sharon E. Nicholson and thank Valerie Trouet for linguistic help and useful comments on an earlier version of the manuscript. Finally we thank two anonymous reviewers and the Editor for their valuable comments and suggestions.

\section{REFERENCES CITED}

Borchert, R., 1994. Water status and development of tropical trees during seasonal drought. Trees-Structure and Function $8: 115-125$.

Borchert, R., G. Rivera, and W. Hagnauer, 2002. Modification of vegetative phenology in a tropical semi-deciduous forest by abnormal drought and rain. Biotropica 34:27-39.

Borella, S., M. Leuenberger, M. Saurer, and R. Siegwolf, 1998. Reducing uncertainties in $\delta^{13} \mathrm{C}$ analysis of tree rings: Pooling, milling, and cellulose extraction. Journal of Geophysical Research-Atmospheres 103:19519-19526.
Brienen, R. J. W., and P. A. Zuidema, 2005. Relating tree growth to rainfall in Bolivian rain forests: A test for six species using tree-ring analysis. Oecologia 146:1-12.

Brienen, R. J. W., and Zuidema, P. A. 2006. The use of tree rings in tropical forest management. Projecting timber yields of four Bolivian tree species. Forest Ecology and Management 226:256-267

Callado, C. H., S. J. D. Neto, F. R. Scarano, and C. G. Costa, 2001. Periodicity of growth rings in some flood-prone trees of the Atlantic Rain Forest in Rio de Janeiro, Brazil. TreesStructure and Function 15:492-497.

Cunningham, S. C., 2004. Stomatal sensitivity to vapour pressure deficit of temperate and tropical evergreen rainforest trees of Australia. Trees-Structure and Function 18:399-407.

Cunningham, S. C. 2005. Photosynthetic responses to vapour pressure deficit in temperate and tropical evergreen rainforest trees of Australia. Oecologia 142:521-528.

Danis, P. A., V. Masson-Delmotte, M. Stievenard, M. T. Guillemim, V. Daux, P. Naveau, and U. von Grafenstein, 2006. Reconstruction of past precipitation $\delta^{18} \mathrm{O}$ using treering cellulose $\delta^{18} \mathrm{O}$ and $\delta^{13} \mathrm{C}$ : A calibration study near Lac d'Annecy, France. Earth and Planetary Science Letters 243: 439-448.

Dünisch, O., and J. Puls, 2003. Changes in content of reserve materials in an evergreen, a semi-deciduous, and a deciduous Meliaceae species from the Amazon. Journal of Applied Botany 77:10-16.

Ehleringer, J. R., and T. A. Cooper, 1988. Correlations between carbon isotope ratio and microhabitat in desert plants. Oecologia 76:562-566.

Ehleringer, J. R., C. B. Field, Z. F. Lin, and C. Y. Kuo, 1986. Leaf carbon isotope and mineral-composition in subtropical plants along an irradiance cline. Oecologia 70:520-526.

Esper, J., E. R. Cook, and F. H. Schweingruber, 2002. Lowfrequency signals in long tree-ring chronologies for reconstructing past temperature variability. Science 295: 2250-2253.

Farquhar, G. D., J. R. Ehleringer, and K. T. Hubick, 1989. Carbon isotope discrimination and photosynthesis. Annual Review of Plant Physiology and Plant Molecular Biology 40: 503-537.

Fichtler, E., D. A. Clark, and M. Worbes, 2003. Age and longterm growth of trees in an old-growth tropical rain forest, based on analyses of tree rings and C-14. Biotropica 35: 306-317.

Fichtler, E., V. Trouet, H. Beeckman, P. Coppin, and M. Worbes, 2004. Climatic signals in tree rings of Burkea africana and Pterocarpus angolensis from semiarid forests in Namibia. Trees-Structure and Function 18:442-451.

Frankie, G. W., H. G. Bake, and P. A. Opler, 1974. Comparative phenological studies of trees in tropical wet and dry forests in lowlands of Costa Rica. Journal of Ecology 62:881-919.

Gagen, M., D. McCarroll, and J. L. Edouard, 2006. Combining ring width, density and stable carbon isotope proxies to enhance the climatic signal in tree rings: An example from the southern French Alps. Climatic Change 78:363-379. 
Gebrekirstos, A., M. Worbes, D. Teketay, M. Fetene, and R. Mitlöhner, 2009. Stable carbon isotopes ratios in tree rings of co-occurring species from semi-arid tropics in Africa: Patterns and climatic signals. Global and Planetary Change 66:253-260.

Gourlay, I. D., 1995. Growth ring characteristics of some African Acacia species. Journal of Tropical Ecology 11: 121-140.

Harlow, B. A., J. D. Marshall, and A. P. Robinson, 2006. A multi-species comparison of $\delta^{13} \mathrm{C}$ from whole wood, extractive-free wood and holocellulose. Tree Physiology 26: $767-774$

Helle, G., and G. H. Schleser, 2004. Beyond $\mathrm{CO}_{2}$-fixation by Rubisco - an interpretation of ${ }^{13} \mathrm{C} /{ }^{12} \mathrm{C}$ variations in tree rings from novel intra-seasonal studies on broad-leaf trees. Plant, Cell and Environment 27:367-380.

Hietz, P., W. Wanek, and O. Dünisch, 2005. Long-term trends in cellulose $\delta^{13} \mathrm{C}$ and water-use efficiency of tropical Cedrela and Swietenia from Brazil. Tree Physiology 25:745-752.

Kaennel, M., and F. H. Schweingruber, 1995. Multilingual Glossary of Dendrochronology. Terms and definitions in English, German, French, Spanish, Italian, Portuguese and Russian. Birmensdorf, Swiss Federal Institute for Forest, Snow and Landscape Research. Berne Stuttgart, Vienna, Haupt.

Leavitt, S. W., 2002. Prospects for reconstruction of seasonal environment from tree-ring $\delta^{13} \mathrm{C}$ : Baseline findings from the Great Lakes area, USA. Chemical Geology 192:47-58.

Leavitt, S. W., and A. Long, 1989. Drought indicated in C-13/ C-12 ratios of southwestern tree rings. Water Resources Bulletin 25:341-347.

Leavitt, S. W., and A. Long, 1991. Seasonal stable-carbon isotope variability in tree rings - possible paleoenvironmental signals. Chemical Geology 87:59-70.

Livingston, N. J., R. D. Guy, Z. J. Sun, and G. J. Ethier, 1999. The effects of nitrogen stress on the stable carbon isotope composition, productivity and water use efficiency of white spruce (Picea glauca (Moench) Voss) seedlings. Plant Cell and Environment 22:281-289.

Loader, N. J., I. Robertson, and D. McCarroll, 2003. Comparison of stable carbon isotope ratios in the whole wood, cellulose and lignin of oak tree-rings. Palaeogeoraphy Palaeoclimatology Palaeoecology 196:395-407.

McCarroll, D., and N. J. Loader, 2004. Stable isotopes in tree rings. Quaternary Science Reviews 23:771-801.

Menezes, M., U. Berger, and M. Worbes, 2003. Annual growth rings and long term growth patterns of mangrove trees from the Braganca Peninsula, Northern Brazil. Wetlands Ecology and Management 11:233-242.

Oldenborgh, G. J. van., and G. Burgers, 2005. Searching for decadal variations in ENSO precipitation teleconnections. Geophysical Research Letters 32:L15701. doi:10.1029/ 2005GL023110.

Ortiz, J., L. Hernandez, and M. Worbes, 2006. Crecimiento radial de Tachigali y Terminalia en bosque de tierra baja al sureste de Venezuela. Acta Botanica Venezuelica 29:211-234.

OTS, 2007. Http://www.ots.duke.edu/en/laselva/metereological. shtml, metereological data. Organization for Tropical Studies, 90630 Durham, USA.
Robertson, I., N. J. Loader, C. A. Froyd, N. Zambatis, I. Whyte, and S. Woodborne, 2006. The potential of the baobab (Adansonia digitata L.) as a proxy climate archive. Applied Geochemistry 21:1674-1680.

Schleser, G. H., and R. Jayasekera, 1985. $\delta^{13} \mathrm{C}$ variations of leaves in forests as an indication of reassimilated $\mathrm{CO}_{2}$ from the soil. Oecologia 65:536-542.

Schöngart, J., W. J. Junk, M. T. F. Piedade, J. M. Ayres, A. Hüttermann, and M. Worbes, 2004. Teleconnection between tree growth in the Amazonian floodplains and the El NinoSouthern Oscillation effect. Global Change Biology 10: 683-692.

Schöngart, J., B. Orthmann, K. J. Hennenberg, S. Porembski, and M. Worbes, 2006. Climate-growth relationships of tropical tree species in West Africa and their potential for climate reconstruction. Global Change Biology 12:11391150.

Schweingruber, F. H., 1996. Tree Rings and Environment. Dendroecology. Birmensdorf, Swiss Federal Institute for Forest, Snow and Landscape Research. Berne Stuttgart, Vienna, Haupt; 609 pp.

Schwendenmann, L., E. Veldkamp, T. Brenes, J. J. O’Brien, and J. Mackensen, 2003. Spatial and temporal variation in soil $\mathrm{CO}_{2}$ efflux in an old-growth neotropical rain forest, La Selva, Costa Rica. Biogeochemistry 64:111-128.

Stahle, D. W., P. T. Mushove, M. K. Cleaveland, F. Roig, and G. A. Haynes, 1999. Management implications of annual growth rings in Pterocarpus angolensis from Zimbabwe. Forest Ecology and Management 124:217229.

Tarhule, A., and S. W. Leavitt, 2004. Comparison of stablecarbon isotope composition in the growth rings of Isoberlinia doka, Daniella oliveri, and Tamarindus indica and West African climate. Dendrochronologia 22:61-70.

Trouet, V., P. Coppin, and H. Beeckman, 2006. Annual growth ring patterns in Brachystegia spiciformis reveal influence of precipitation on tree growth. Biotropica 38:375-382.

USDA, NRCS, 2007. The PLANTS Database, http://plants. usda.gov. National Plant Data Center, Baton Rouge, LA 708744490 USA.

Van de Water, P. K., 2002. The effect of chemical processing on the $\delta^{13} \mathrm{C}$ value of plant tissue. Geochimica et Cosmochimica Acta 66:1211-1219.

Verheyden, A., J. G. Kairo, H. Beeckman, and N. Koedam, 2004a. Growth rings, growth ring formation and age determination in the mangrove Rhizophora mucronata. Annals of Botany 94:59-66.

Verheyden, A., G. Helle, G. H. Schleser, F. Dehairs, H. Beeckman, and N. Koedam, 2004b. Annual cyclicity in highresolution stable carbon and oxygen isotope ratios in the wood of the mangrove tree Rhizophora mucronata. Plant Cell and Environment 27:1525-1536.

Walter, H., and H. Lieth, 1967. Klimadiagramm-Weltatlas. Gustav Fischer Verlag, Jena, Jena, Germany.

Worbes, M., 1999a. Degradacion e historia de la Vegetacion boscosa de la Gran Sabana. In Ecologia de la Altiplanicie de la Gran Sabana, edited by L. Hernandez, pp. 84-107. Koeltz Scientific Books, Germany. 
Worbes, M., 1999b. Annual growth rings, rainfall-dependent growth and long-term growth patterns of tropical trees from the Caparo Forest Reserve in Venezuela. Journal of Ecology 87:391-403.

Worbes, M., 2002. One hundred years of tree-ring research in the tropics - a brief history and an outlook to future challenges. Dendrochronologia 20:217-231.
Worbes, M., R. Staschel, A. Roloff, and W. J. Junk, 2003. Treering analysis reveals age structure, dynamics and wood production of a natural forest stand in Cameroon. Forest Ecology and Management 173:105-123.

Received 3 December 2008; accepted 10 September 2009. 